\title{
Gypsum, Soil Scarification and Succession Planting as Alternatives to Mitigate Compaction of Dystrophic Red-Yellow Latosol
}

\author{
Eduardo Antonio Neves dos Santos ${ }^{1}$, Milton César Costa Campos $^{1}$, José Maurício da Cunha ${ }^{1}$, \\ Fernando Gomes de Souza ${ }^{2}$, Paulo Guilherme Salvador Wadt ${ }^{3}$, Elyenayra Nogueira Pinheiro ${ }^{1}$, \\ Half Weinberg Corrêa Jordão ${ }^{1}$, Alan Ferreira Leite de Lima ${ }^{1}$, Wildson Benedito Mendes Brito ${ }^{1}$ \\ $\&$ Ludmila Freitas ${ }^{4}$ \\ ${ }^{1}$ Instituto de Educação, Agricultura e Ambiente, Universidade Federal do Amazonas, Humaitá, AM, Brazil \\ ${ }^{2}$ Instituto Federal de Educação, Ciências e Tecnologia de Rondônia, Colorado do Oeste, RO, Brazil \\ ${ }^{3}$ Empresa Brasileira de Pesquisa Agropecuária, Centro de Pesquisa Agroflorestal de Rondônia, Porto Velho, RO, \\ Brazil \\ ${ }^{4}$ University of São Paulo State, Jaboticabal, SP, Brazil \\ Correspondence: Milton César Costa Campos, Instituto de Educação, Agricultura e Ambiente, Universidade \\ Federal do Amazonas, Humaitá, AM, 69800-000, Brazil. Tel: 55-97-8114-4618. E-mail: \\ mcesarsolos@gmail.com
}

Received: February 18, 2018

Accepted: May 1, $2018 \quad$ Online Published: July 15, 2018

doi:10.5539/jas.v10n8p277

URL: https://doi.org/10.5539/jas.v10n8p277

\begin{abstract}
Understanding and quantifying the impact of soil management and use on its physical properties are essential to the development of sustainable agricultural systems. Thus, the aim of this study was to assess the effect of agricultural gypsum, soil scarification and succession planting on the physical attributes of dystrophic red-yellow latosol in Porto Velho, Rondônia state (RO), Brazil. The treatments used were absence and application of 2000 $\mathrm{kg} \mathrm{ha}^{-1}$ of gypsum, absence and use of soil scarification, and three types of crop succession: SF (soybean/fallow), SMF (soybean/maize/fallow) and SMBF (soybean/maize/brachiaria/fallow). A randomized block design was used on eight blocks, for a $2 \times 2 \times 3$ factorial arrangement. Soil parameters assessed were macroporosity, microporosity, total porosity, soil density, moisture content and penetration resistance. Data normality was assessed using the Shapiro-Wilk test. The data were submitted to analysis of variance and means were compared by the Scott-Knott test at 5\% probability. The highest macroporosity and total porosity values were recorded in treatments with gypsum application and soil scarification. Penetration resistance was lower in the SMBF and SMF crop successions. There was no treatment effect on the soil density.
\end{abstract}

Keywords: soil physical attributes, soil management, crop succession

\section{Introduction}

Correct soil management is vital to optimum crop development. Proper soil management aims to reconcile efficient production systems with the conservation of natural and especially nonrenewable resources; however, this cannot always be fully achieved because many agricultural practices significantly affect the environment (Carvalho, Goedert, \& Armando, 2014). Inadequate soil management, such as excessive tillage, can increase soil density and reduce macroporosity and total porosities (Soares, Campos, Oliveira, Cunha, \& Santos, 2016), which may hamper crop development (Vitória, Fernandes, Texeira, \& Cecon, 2014; Lamas, Ferreira, La Torre, \& Staut, 2016). As such, these characteristics should be monitored in order to assess the quality of soil management (Bertol, Albuquerque, Leite, Amaral, \& Zoldan Júnior, 2004). No-till and minimum tillage are recommended as management systems capable of recovering the natural structure of the soil, since limiting soil turning and the use of agricultural machinery associated with cover crops contributes to preserving or recovering soil structure.

However, even conservation-oriented systems can result in loss of physical property; for example, in no-till farming agricultural lime is only applied to the surface, which can lead to excessively high $\mathrm{pH}$ levels, clay dispersion and subsurface compaction at a depth of 0.1 to $0.2 \mathrm{~m}$ (Debiasi, Levien, Trein, Conte, \& Kamimura, 2010). 
Soil structural problems can be mitigated, in principle, using different management techniques. One of these is the introduction of forage grasses into soybean-maize succession systems (Brancalião \& Moraes, 2008), since the root system of grasses may contribute to the formation of well-developed soil (Andrade, Stone, \& Silveira, 2009).

Another alternative is the application of gypsum on the surface, which contributes to reducing clay dispersion and thereby decreases subsurface compaction (Raij, 2008; Ramos et al., 2013). Another recommended practice to mitigate these effects is soil scarification, which involves breaking up the dense layers to allow the development of deep root systems.

In this context, the aim of this study was to assess the effect of agricultural gypsum, soil scarification and succession planting on the physical attributes of dystrophic red-yellow latosol.

\section{Material and Methods}

\subsection{Materials}

\subsubsection{The Experimental Area}

The study was carried out in the experimental area of the Embrapa Rondonia, in the municipality of Porto Velho, Rondônia state, Brazil (Figure 1). It began in 2013 for the 2014 growing season. The climate in the region is Am, according to Köppen's classification, defined as tropical wet, with an average annual temperature of $24.9^{\circ} \mathrm{C}$ and $89 \%$ relative humidity. Average rainfall varies between 2,000 and 2,200 mm, with a dry season from June to September. The soil was classified as dystrophic red-yellow Latosol (Embrapa, 2013).

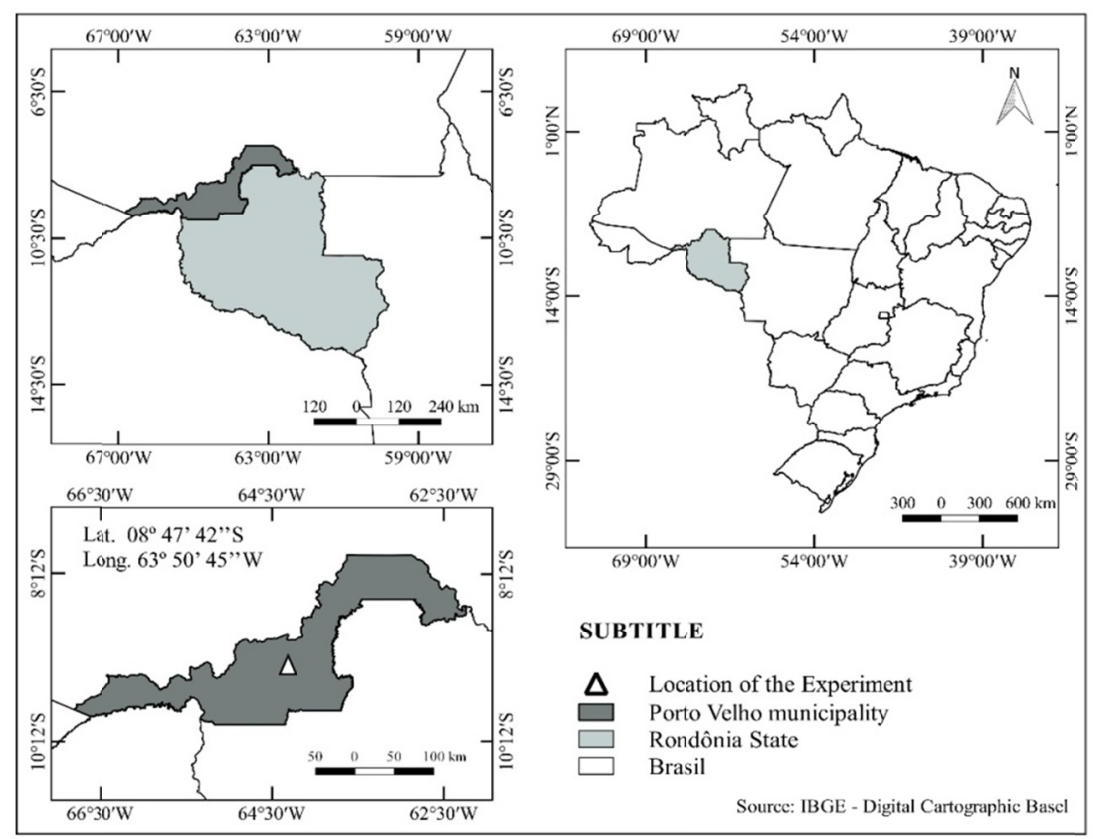

Figure 1. Location of the study area

Prior to the study, the area was cultivated with Brachiaria brizantha cv. Marandu for eighteen years (1990 to 2008) and then left in fallow for four years (2009 to 2013), after which the experiment was installed. The seeds used for soybean, maize and brachiaria planting were those available and recommended for the Southern Cone region of Rondônia.

\subsection{Methods}

A randomized block design was used in eight blocks, for a $2 \times 2 \times 3$ factorial arrangement. The treatments used were: zero mechanical soil scarification and mechanical soil scarification, zero application of gypsum and application of gypsum, and three crop succession systems including soybean/fallow (SF), soybean/maize/fallow (SMF), and soybean/maize and brachiaria/fallow (SMBF). Each plot measured $4.5 \mathrm{~m}$ by $20 \mathrm{~m}$ and each block $27 \mathrm{~m}$ by $40 \mathrm{~m}$, for a total experimental area of $160 \mathrm{~m}$ by $54 \mathrm{~m}$, excluding the borders. Soil scarification was performed to 
a depth of 30 to $35 \mathrm{~cm}$, with the scarifier blades spaced $30 \mathrm{~cm}$ apart, and the gypsum dose used was $2,000 \mathrm{~kg} \mathrm{ha}^{-1}$. Both treatments were applied in 2013, the first year of the experiment, before soybean was planted. Planting densities were of 260,000 to 340,000 plants ha ${ }^{-1}$ for soybean, 50,000 to 70,000 plants ha ${ }^{-1}$ for maize and $16 \mathrm{~kg} \mathrm{ha}^{-1}$ of brachiaria seeds.

Soybean was planted in November 2013, December 2014, December 2015 and November 2016; maize and brachiaria were always planted 30 days after soybean harvesting. Soybean and maize were planted by mechanical seed drilling and brachiaria by manual broadcasting.

Fertilization was performed using the following NPK formulations: $400 \mathrm{~kg}^{-1}$ of 0-30-15 at soybean planting, plus $300 \mathrm{~kg} \mathrm{ha}^{-1}$ of 4-30-10 at maize planting (with or without brachiaria) and $150 \mathrm{~kg} \mathrm{ha}^{-1}$ of $25-0-25$ as topdressing for maize crops (with or without brachiaria), 30 days after germination.

\subsection{Analyses}

\subsubsection{Soil Chemical Analyses}

Prior to the study, the soil was sampled at a depth of 0.0-0.20 m for chemical characterization. The attributes assessed were $\mathrm{pH}\left(\mathrm{H}_{2} \mathrm{O}\right), \mathrm{Ca}^{2+}, \mathrm{Mg}^{2+}, \mathrm{K}^{+}, \mathrm{Al}^{3+},\left(\mathrm{H}^{+}+\mathrm{Al}^{3+}\right)$, and $\mathrm{P} . \mathrm{Ca}^{2+}, \mathrm{Mg}^{2+}$ and $\mathrm{Al}^{3+}$ were determined by titration using $1.0 \mathrm{~mol} \mathrm{~L}^{-1} \mathrm{KCl}$ for extraction. $\mathrm{P}$ and $\mathrm{K}^{+}$were extracted using Mehlich-1, with $\mathrm{P}$ determined by colorimetry and $\mathrm{K}^{+}$by flame photometry. Potential acidity $\left(\mathrm{H}^{+}+\mathrm{Al}^{3+}\right)$ was determined by titration, using $0.5 \mathrm{~mol} \mathrm{~L}^{-1}$ of calcium acetate for extraction. The analyses were performed in accordance with the methodologies described by Embrapa (2011).

\subsubsection{Soil Physical Analyses}

In October 2016, undisturbed soil samples were collected using volumetric rings at depths of 0.0-0.05, 0.05-0.10, $0.10-0.20 \mathrm{~m}$ in each plot. These samples were used to determine porosity, penetration resistance, density and moisture, as described below. Disturbed samples were also collected to determine soil texture, with one sample per treatment, at depths of 0.0-0.05, 0.05-0.10, 0.10-0.20 m.

Soil texture was determined using the pipette method, by dispersing the soil in $1 \mathrm{~mol} \mathrm{NaOH}$ solution followed by mechanical agitation in a high-speed stirrer for 15 minutes, in line with Embrapa recommendations (2011). The clay fraction was separated by sedimentation, course and fine sand by sieving, and silt was calculated by deduction from the other fractions.

Porosity was determined on a tension table, where the samples were submitted to pressure of $6 \mathrm{MPa}$ to remove water from the macropores $(\geq 0.05 \mathrm{~mm}$ diameter). Macropores were estimated as a difference between the saturated soil moisture content and moisture content after the application of pressure. The volume of the micropores was estimated as the moisture content retained when pressure was applied. After drainage, the samples were dried in an oven at $105^{\circ} \mathrm{C}$ for $24 \mathrm{~h}$ to determine soil density (Embrapa, 2011).

The mechanical resistance to penetration of the soil was determined using a Marconi MA-933 penetrometer with a constant speed of $4 \mathrm{~mm} \mathrm{~s}^{-1}$, equipped with a $200 \mathrm{~N}$ load cell and a cylindrical probe with a cone-shaped tip (4 $\mathrm{mm}$ wide, a semi-angle of $30^{\circ}$ ). The receptor and interface were coupled to a microcomputer, in order to record the readings in the equipment software (Dalchiavon et al., 2011).

\subsubsection{Statistical Analyses}

Data normality was assessed using the Shapiro-Wilk test. The data were submitted to analysis of variance and, when significant was revealed, means were compared by the Scott-Knott test at $5 \%$ probability.

\section{Results and Discussion}

\subsection{Chemical Characterization of the Soil}

Table 1 shows the results of soil chemical analysis before the study.

Table 1. Chemical analysis of the soil in the experimental area in the $0.00-0.20 \mathrm{~m}$ layer

\begin{tabular}{|c|c|c|c|c|c|c|c|c|}
\hline $\mathrm{pH}$ & $\mathrm{Ca}^{2+}+\mathrm{Mg}^{2+}$ & $\mathrm{K}^{+}$ & $\mathrm{Al}^{3+}$ & $\mathrm{H}^{+}+\mathrm{Al}^{3+}$ & $\mathrm{T}$ & SBC & $\mathrm{OM}$ & Available P \\
\hline $\mathrm{H}_{2} \mathrm{O}$ & \multicolumn{6}{|c|}{ 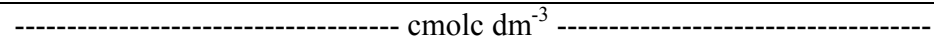 } & \multicolumn{2}{|c|}{--------- $\mathrm{mg} \mathrm{dm} \mathrm{dm}^{-3}$} \\
\hline 5.0 & 1.7 & 0.12 & 2.2 & 5.9 & 7.7 & 1.73 & 3.2 & 1.4 \\
\hline
\end{tabular}

Note. $\mathrm{pH}$ : In water; SBC: sum of base cations; T: $\mathrm{CEC}$ at $\mathrm{pH}$ 7.0; OM: organic matter. 


\subsection{Physical Attributes of the Soil}

\subsubsection{Porosity and Density}

Gypsum application at 0.00-0.05 m increased macroporosity (MaP) and reduced microporosity (MiP) (Table 2). These findings corroborate those of Silva and Kay (1997), who reported that micropores are relatively less affected by soil management than macropores, since microporosity is related to the arrangement of isolated primary mineral particles and microaggregates. The results of the Shapiro-Wilk test indicated data normality for all the variables studied.

In general, gypsum can facilitate root development, providing good soil structure and resulting in decreased microporosity (MiP), which, in turn, is counterbalanced by increased MaP and total porosity (Tp). Albeit to a lesser extent, the same behavior was observed at 0.05-0.10 m, given that the highest MaP value was recorded in the gypsum treatment (Table 2).

No significant differences were observed in the physical attributes tested for the gypsum treatment at $0.10-0.20$ $\mathrm{m}$ (Table 2). These results are consistent with those reported by Lima, Pauletto, Gomes, Hartwig, and Passianoto (2006), who studied planosol compaction as a function of management systems and found that treatments with and without gypsum did not affect MaP, MiP, Tp and soil density (Sd) at depths of 0.15-0.30 and 0.30-0.45 m.

Soil scarification did not influence any of the physical attributes tested in the 0.00-0.05 m layer (Table 2). By contrast, significant differences were observed at depths of 0.05-0.10 and 0.10-0.20 m, with the highest MaP and Pt values recorded in the scarification treatment (Table 2). Similar results were obtained by Araújo, Tormena, Inoue, and Costa (2004), indicating that the persistence of scarification effects is likely associated with greater structural stability of the soil due to root development. Additionally, the same authors reported that using scarifiers results in higher macroporosity and total porosity, but lower microporosity.

Scarification showed no effect on soil density (SD) in any of the layers assessed (Table 2). These findings are in accordance with Nagahama, Granja, Cortez, Ramos, and Arcoverde (2016), who found no differences in SD before and after scarification in the three soil layers studied. However, Evans, Lindstrom, Voorhees, Mocrief, and Nelson (1996) argued that soil density, determined by the volumetric ring technique, was relatively insensitive to the effect of scarification, which could explain the lack of statistical difference between treatments.

With respect to the effect of succession planting, lower MaP values were observed for the SMBF and SMF systems in all three layers assessed. In the soybean/fallow (SF) system, the highest MaP and $\mathrm{Tp}$ values were recorded at 0.10-0.20 m (Table 2). Bertol, Albuquerque, Leite, Amaral, and Zoldan Júnior (2004) found no variation in soil physical properties using different cropping systems, including crop rotation and succession; however, the authors only studied one production cycle and suggested further investigations to assess the effect over a longer time period.

By contrast, the higher MaP in the SF system may be related to the less intense soil management strategy in the area, since less machinery is used (no machines for planting, management and harvesting of the succession crop). This is corroborated by Streck, Reinert, Reichert, and Kaiser (2004), who reported that the movement of a tractor over the soil during harvesting caused a reduction in macropores as a result of the pressure exerted by the tractor on the surface. 
Table 2. Mean values for macroporosity (MaP), microporosity (MiP), total porosity (Tp) and soil density (SD) as a function of agricultural gypsum, soil scarification and crop succession systems at different soil depths

\begin{tabular}{|c|c|c|c|c|c|c|c|c|c|c|c|c|c|}
\hline \multirow{2}{*}{ Treatments } & & \multicolumn{4}{|c|}{$0.00-0.05 \mathrm{~m}$} & \multicolumn{4}{|c|}{$0.05-0.10 \mathrm{~m}$} & \multicolumn{4}{|c|}{$0.10-0.20 \mathrm{~m}$} \\
\hline & & $\mathrm{MaP}$ & MiP & $\mathrm{Tp}$ & SD & $\mathrm{MaP}$ & MiP & $\mathrm{Tp}$ & SD & $\mathrm{MaP}$ & MiP & $\mathrm{Tp}$ & SD \\
\hline \multirow{3}{*}{ Gypsum } & & -------- & $\mathrm{m}^{3} \mathrm{~m}^{-3}-$ & ----- & $\mathrm{kg} \mathrm{dm}^{-3}$ & ------- & $\mathrm{m}^{3} \mathrm{~m}^{-3}$ & -------- & $\mathrm{kg} \mathrm{dm}^{-3}$ & \multicolumn{3}{|c|}{--------- $\mathrm{m}^{3} \mathrm{~m}^{-3}$-------- } & $\mathrm{kg} \mathrm{dm}^{-3}$ \\
\hline & With & $0.16 \mathrm{a}$ & $0.40 \mathrm{~b}$ & 0.56 & 0.90 & $0.14 \mathrm{a}$ & 0.41 & 0.55 & 1.03 & 0.13 & 0.43 & 0.56 & 1.05 \\
\hline & Without & $0.14 \mathrm{~b}$ & $0.43 \mathrm{a}$ & 0.57 & 0.89 & $0.12 b$ & 0.42 & 0.54 & 1.01 & 0.12 & 0.43 & 0.56 & 1.06 \\
\hline ANOVA & & $*$ & $*$ & ns & $\mathrm{ns}$ & $* *$ & ns & $\mathrm{ns}$ & ns & $\mathrm{ns}$ & ns & ns & $\mathrm{ns}$ \\
\hline \multirow[t]{2}{*}{ Scarification } & With & 0.14 & 0.42 & 0.56 & 0.89 & $0.14 \mathrm{a}$ & 0.42 & $0.56 \mathrm{a}$ & 1.00 & $0.14 \mathrm{a}$ & 0.43 & $0.57 \mathrm{a}$ & 1.06 \\
\hline & Without & 0.14 & 0.42 & 0.56 & 0.90 & $0.12 \mathrm{~b}$ & 0.42 & $0.54 b$ & 1.04 & $0.12 b$ & 0.43 & $0.55 \mathrm{~b}$ & 1.05 \\
\hline ANOVA & & ns & ns & ns & $\mathrm{ns}$ & $* *$ & ns & $* *$ & ns & $* *$ & ns & $* *$ & $\mathrm{~ns}$ \\
\hline \multirow[t]{3}{*}{ Succession } & SMBF & $0.14 \mathrm{~b}$ & 0.42 & 0.56 & 0.90 & $0.13 \mathrm{~b}$ & 0.42 & 0.55 & 1.03 & $0.12 \mathrm{~b}$ & 0.43 & $0.55 \mathrm{~b}$ & 1.06 \\
\hline & SMF & $0.14 \mathrm{~b}$ & 0.42 & 0.56 & 0.89 & $0.13 \mathrm{~b}$ & 0.42 & 0.55 & 1.01 & $0.12 \mathrm{~b}$ & 0.44 & $0.56 \mathrm{~b}$ & 1.05 \\
\hline & SF & $0.15 \mathrm{a}$ & 0.42 & 0.57 & 0.89 & $0.15 \mathrm{a}$ & 0.41 & 0.56 & 1.03 & $0.14 \mathrm{a}$ & 0.43 & $0.57 \mathrm{a}$ & 1.06 \\
\hline ANOVA & & $* *$ & ns & ns & $\mathrm{ns}$ & $*$ & ns & ns & ns & $* *$ & ns & $*$ & ns \\
\hline
\end{tabular}

Note. $\mathrm{SMBF}=$ soybean/maize/brachiaria/fallow; SMF $=$ soybean/maize/fallow; SF $=$ soybean/fallow; ** significant at $1 \%$ probability $(\mathrm{p}<.01) ; *$ significant at $5 \%$ probability $(0.01 \leq \mathrm{p}<0.05) ; \mathrm{ns}=$ not significant $(\mathrm{p} \geq$ 0.05). Means followed by the same lowercase letter do not differ according to the Scott-Knott test at $5 \%$ probability.

A general analysis indicated that, in the three layers assessed, all the succession systems exhibited MaP values higher than the critical threshold of $0.10 \mathrm{~m}^{3} \mathrm{~m}^{-3}$ stipulated in the literature (Klein, 2008). Microporosity (MiP), responsible for storing water in the soil profile, remained unchanged in the successions systems in the three layers studied (Table 2), indicating that this physical property is not sensitive to the varying root systems of different plants in crop rotation or succession planting.

In the three layers studied (Table 2), all the succession systems obtained similar soil density (SD) results, demonstrating no significant effect for the species used and therefore making it impossible to identify the succession systems most effective at improving this physical attribute.

Bertol et al. (2004) also found no significant effect in SD values for different crop succession-rotation systems. Similarly, Abreu, Reichert, and Reinert (2004), found that the advantage of including cover crops is primarily linked to the creation of biopores highly efficient at soil aeration and water filtration. These pores typically represent less than $3 \%$ of soil volume and their formation slightly reduces soil density. It is important to underscore that these studies obtained significant results because the experiments were long-term. Reinert, Albuquerque, Reichert, Aita, and Andrada (2008) suggested that SD values of approximately $1.85 \mathrm{Mg} \mathrm{m}^{-3}$ restrict plant development, according to the silt + clay content of the soil. The mean SD values obtained in the present study did not exceed this threshold, irrespective of the treatments assessed.

\subsubsection{Soil Penetration Resistance and Gravimetric Water Content}

Soil penetration resistance (PR) includes the effects of density and moisture on the physical conditions needed for root growth. The results of PR assessment are presented in Table 3. Gypsum application showed no effect on PR in any of the soil layers studied. These results are in agreement with Oliveira et al. (2017), who studied the residual effect of gypsum on soil penetration resistance and also observed no differences in the soil conditioning systems assessed.

Scarification showed no effect on PR in the three layers studied (Table 3). These findings may be related to the shorter residual effect of scarification, which may be less than the four years between treatment application and its assessment, meaning it does not persist over time.

Drescher et al. (2016) evaluated the persistence of decompaction by mechanical scarification in a typical dystrophic red latosol under no-till farming and found that changes in PR were observed 18 months after scarification. However, Colonego and Rosolem (2008) observed that the effects of scarification on soil physical properties do not persist for more than three years. Several authors have reported that the mobilization effect disappears as a result of soil wetting and drying cycles, the impact of raindrops, and the movement of agricultural machinery used for planting, harvesting and crop treatment (Veiga, Reichert, \& Kaiser, 2008; Reichert et al., 2009).

A possible explanation for the lower PR values in the SMBF and SMF systems at depths of 0.00-0.05 and 0.05-0.10 m may be related to the greater root density of the crops used and higher organic carbon content 
resulting from the residues generated by these systems; however, these attributes were not analyzed. In addition to these effects, planting mobilizes the soil surface and can reduce PR.

The PR values recorded here were below the critical threshold reported in the literature (2.0 MPa) (Lal, 1999). In all the succession systems, penetration resistance values for the surface layer were lower than $1 \mathrm{MPa}$, which may be due to the greater effect of wetting and drying cycles as well as biological activity.

Table 3. Mean values for soil penetration resistance (PR) and gravimetric moisture (GM) content as a function of gypsum, soil scarification and crop succession systems at different soil depths

\begin{tabular}{|c|c|c|c|c|c|c|c|}
\hline \multirow{2}{*}{ Treatments } & & \multicolumn{3}{|c|}{ PR (MPa) } & \multicolumn{3}{|c|}{$\mathrm{GM}\left(\mathrm{kg} \mathrm{kg}^{-1}\right)$} \\
\hline & & $0.0-0.05 \mathrm{~m}$ & $0.05-0.10 \mathrm{~m}$ & $0.10-0.20 \mathrm{~m}$ & $0.0-0.05 \mathrm{~m}$ & $0.05-0.10 \mathrm{~m}$ & $0.10-0.20 \mathrm{~m}$ \\
\hline \multirow[t]{2}{*}{ Gypsum } & With & 0.78 & 1.25 & 1.26 & 0.45 & 0.46 & 0.41 \\
\hline & Without & 0.86 & 1.20 & 1.24 & 0.43 & 0.48 & 0.40 \\
\hline ANOVA & & ns & ns & ns & ns & ns & ns \\
\hline \multirow[t]{2}{*}{ Scarification } & With & 0.82 & 1.15 & 1.21 & 0.39 & 0.48 & 0.40 \\
\hline & Without & 0.82 & 1.30 & 1.29 & 0.42 & 0.47 & 0.41 \\
\hline ANOVA & & ns & ns & ns & ns & ns & ns \\
\hline \multirow[t]{3}{*}{ Succession } & SMBP & $0.76 \mathrm{~b}$ & $1.00 \mathrm{~b}$ & 1.32 & $0.43 \mathrm{a}$ & 0.47 & 0.40 \\
\hline & SMP & $0.75 \mathrm{~b}$ & $1.03 \mathrm{~b}$ & 1.37 & $0.41 \mathrm{~b}$ & 0.47 & 0.42 \\
\hline & SP & $0.95 \mathrm{a}$ & $1.30 \mathrm{a}$ & 1.39 & $0.39 \mathrm{~b}$ & 0.48 & 0.41 \\
\hline ANOVA & & $*$ & $*$ & ns & $* *$ & ns & ns \\
\hline
\end{tabular}

Note. $\mathrm{SMBF}=$ soybean $/ \mathrm{maize} /$ brachiaria/fallow; SMF $=$ soybean $/$ maize/fallow; SF $=$ soybean/fallow; $* *$ significant at $1 \%$ probability $(\mathrm{p}<.01) ;{ }^{*}$ significant at $5 \%$ probability $(0.01 \leq \mathrm{p}<0.05) ;$ ns $=$ not significant $(\mathrm{p} \geq$ 0.05 ). Means followed by the same lowercase letter do not differ according to the Scott-Knott test at $5 \%$ probability.

Although soil moisture content is highly dependent on factors of different origin, significant differences in this indicator were observed for the successions systems at 0.00-0.05 $\mathrm{m}$ (Table 3), and the highest value was recorded for the SMBF system, which may be due to soil exposure to external factors, leading to moisture losses in the remaining systems. This corroborates the findings of Dalmago et al. (2009), who observed that straw on the surface led to greater soil water storage, reducing evaporation and increasing infiltration (Fabrizzi, Garcia, Costa, $\&$ Picone 2005).

\subsubsection{Soil Texture}

None of the treatments studied affected soil texture (Table 4), which is consistent with the fact that it is not easily modified by soil management systems (Ferreira, 2010; Stone et al., 2012).

Table 4. Mean sand, silt and clay values as a function of gypsum, soil scarification and crop succession systems

\begin{tabular}{|c|c|c|c|c|c|c|c|c|c|c|}
\hline \multirow{2}{*}{ Treatments } & & \multicolumn{3}{|c|}{$0.00-0.05 \mathrm{~m}$} & \multicolumn{3}{|c|}{$0.05-0.10 \mathrm{~m}$} & \multicolumn{3}{|c|}{$0.10-0.20 \mathrm{~m}$} \\
\hline & & Sand & Silt & Clay & Sand & Silt & Clay & Sand & Silt & Clay \\
\hline \multirow{3}{*}{ Gypsum } & & $\mathrm{g} \mathrm{kg}^{-1}$ & & & $\mathrm{~g} \mathrm{~kg}^{-1}$ & & & $\mathrm{~g} \mathrm{~kg}^{-1}$ & & \\
\hline & With & 142.7 & 574.7 & 282.6 & 140.4 & 541.8 & 308.6 & 169.1 & 501.9 & 309.5 \\
\hline & Without & 161.5 & 560.2 & 271.3 & 164.0 & 536.5 & 294.5 & 160.4 & 541.1 & 298.3 \\
\hline ANOVA & & ns & ns & ns & ns & ns & ns & ns & ns & ns \\
\hline Scarification & With & 157.6 & 581.9 & 257.5 & 157.5 & 537.0 & 305.3 & 151.0 & 527.6 & 301.9 \\
\hline & Without & 156.5 & 576.7 & 266.8 & 146.9 & 541.3 & 297.7 & 178.5 & 515.5 & 305.9 \\
\hline ANOVA & & ns & ns & ns & ns & ns & ns & ns & ns & ns \\
\hline \multirow[t]{3}{*}{ Succession } & SMBF & 144.0 & 552.9 & 284.3 & 146.8 & 524.5 & 316.8 & 172.3 & 509.0 & 307.6 \\
\hline & SMF & 167.5 & 557.1 & 270.6 & 153.0 & 544.6 & 298.7 & 157.8 & 529.5 & 304.7 \\
\hline & $\mathrm{SF}$ & 159.9 & 568.2 & 261.0 & 156.8 & 548.3 & 288.9 & 164.1 & 526.1 & 299.4 \\
\hline ANOVA & & ns & $\mathrm{ns}$ & ns & ns & $\mathrm{ns}$ & ns & ns & ns & ns \\
\hline
\end{tabular}

Note. $\mathrm{SMBF}=$ soybean/maize/brachiaria/fallow; SMF $=$ soybean/maize/fallow; SF $=$ soybean/fallow; ${ }^{* *}$ significant at $1 \%$ probability $(\mathrm{p}<.01) ;{ }^{*}$ significant at $5 \%$ probability $(0.01 \leq \mathrm{p}<0.05) ;$ ns $=$ not significant $(\mathrm{p} \geq$ 0.05). Means followed by the same lowercase letter do not differ according to the Scott-Knott test at $5 \%$ probability. 


\section{Conclusions}

Agricultural gypsum altered soil porosity and the highest macroporosity values in the first two layers assessed were observed in treatments that included gypsum application.

The highest macroporosity and total porosity values were recorded in treatments with soil scarification.

Crop succession systems can influence the physical characteristics of soil, with the lowest penetration resistance values found in the SMBF and SMF systems.

\section{References}

Abreu, S. L., Reichert, J. M., \& Reinert, D. J. (2004). Escarificação mecânica e biológica para a redução da compactação em Argissolo franco-arenoso sob plantio direto. Revista Brasileira de Ciência do Solo, 28, 519-531. https://doi.org/10.1590/S0100-06832004000300013

Andrade, R. S., Stone, L. F., \& Silveira, P. M. (2009). Culturas de cobertura e qualidade física de um Latossolo em plantio direto. Revista Brasileira de Engenharia Agrícola e Ambiental, 13(4), 411-418. https://doi.org/ 10.1590/S1415-43662009000400007

Araújo, M. A., Tormena, C. A., Inoue, T. T., \& Costa, A. C. S. (2004). Efeitos da escarificação na qualidade física de um Latossolo Vermelho distroférrico após treze anos de semeadura direta. Revista Brasileira de Ciências do Solo, 28(2), 495-504. https://doi.org/10.1590/S0100-06832004000300011

Bertol, I., Albuquerque, J. A., Leite, D., Amaral, A. J., \& Zoldan Junior, W. A. (2004). Propriedades físicas do solo sob preparo convencional e semeadura direta em rotação e sucessão de culturas, comparadas às do campo nativo. Revista Brasileira de Ciência do Solo, 28(1), 155-163. https://doi.org/10.1590/S0100-0683 2004000100015

Brancalião, S. A., \& Moraes, M. H. (2008). Alterações de alguns atributos físicos e das frações húmicas de um Nitossolo vermelho na sucessão milheto-soja em sistema plantio direto. Revista Brasileira de Ciência do Solo, 32(1), 393-404. https://doi.org/10.1590/S0100-06832008000100037

Calonego, J. C., \& Rosolem, C. A. (2008). Estabilidade de agregados do solo após manejo com rotações de culturas e escarificação. Revista Brasileira de Ciência do Solo, 32(4) 1399-1407. https://doi.org/10.1590/ S0100-06832008000400004

Carvalho, R., Goedert, W. J., \& Armando, M. S. (2014). Atributos físicos da qualidade de um solo sob sistema agroflorestal. Pesquisa Agropecuária Brasileira, 39(1), 1153-1155. https://doi.org/10.1590/S0100-204X200 4001100015

Dalchiavon, F. C., Passos e Carvalho, M. de, Nogueira, D. C., Romano, D., Abrantes, F. L., Assis, J. T. de, \& Oliveira, M. S. de. (2011). Produtividade da soja e resistência mecânica à penetração do solo sob sistema plantio direto no cerrado brasileiro. Pesquisa Agropecuária Tropical, 41(1), 8-19. https://doi.org/10.5216/ pat.v41i1.8351

Dalmago, G. A., Bergamaschi, H., Bergonci J. I., Krüger, C. A. M. B., Comiran, F., \& Heckler, B. M. M. (2009). Retenção e disponibilidade de água às plantas, em solo sob plantio direto e preparo convencional. Revista Brasileira de Engenharia Agrícola e Ambiental, 13, 855-864. https://doi.org/10.1590/S1415-436620 09000700007

Debiasi, H., Levien, R., Trein, C. R., Conte, O., \& Kamimura, K. M. (2010). Produtividade de soja e milho após coberturas de inverno e descompactação mecânica do solo. Pesquisa Agropecuária Brasileira, 45(6), 603-612. Retrieved from https://seer.sct.embrapa.br/index.php/pab/article/view/5579

Drescher, M. S., Reinert, D. J., Denardin, J. E., Gubiani, P. I., Faganello, A., \& Drescher, G. L. (2016). Duração das alterações em propriedades físico-hídricas de Latossolo argiloso decorrentes da escarificação mecânica. Pesquisa Agropecuária Brasileira, 51(2), 159-168. https://doi.org/10.1590/S0100-204X2016000200008

Embrapa (Empresa Brasileira de Pesquisa Agropecuária). (2011). Centro Nacional de Pesquisa de Solos. Manual de métodos de análise de solo (p. 230). Rio de Janeiro, Brazil.

Embrapa (Empresa Brasileira de Pesquisa Agropecuária). (2013). Sistema brasileiro de classificação dos solos (3rd ed., p. 353). Brasília: Brazil.

Evans, S. D., Lindstrom, M. J., Voorhees, W. B., Mocrief, J. F., \& Nelson, G. A. (1996). Effect of subsoiling and subsequent tillage on soil bulk density, soil moisture and corn yield. Soil and Tillage Research, 38(1), 35-46. https://doi.org/10.1016/0167-1987(96)01020-3 
Fabrizzi, K. P., Garcia, F. O., Costa, J. L., \& Picone, L. I. (2005). Soil water dynamics, physical properties and corn and wheat responses to minimum and no-tillage systems in the southern Pampas of Argentina. Soil and Tillage Research, 81(1), 57-69. https://doi.org/10.1016/j.still.2004.05.001

Ferreira, M. F. (2010). Caracterização Física do solo. In Q. de J. van Lier (Ed.), Física do solo (p. 298). Viçosa-MG: Sociedade Brasileira de Ciência do Solo.

Klein, V. A. (2008). Densidade relativa-um indicador da qualidade física de um Latossolo vermelho. Revista de Ciências Agroveterinárias, 5(1), 26-32. Retrieved from http://www.scielo.br/pdf/cr/2009nahead/a394cr 1524.pdf

Lal, R. (1999). Métodos para avaliação do uso sustentável dos recursos solo e água nos trópicos; tradução e adaptação de Cláudia Conti Medugno e José Flávio Dynia. Embrapa Meio Ambiente (Documentos, 03, p. 97). Jaguariúna: Embrapa Meio Ambiente.

Lamas, F. M., Ferreira, A. C. D. B., La Torre, E. de J. R. de, \& Staut, L. A. (2016). Sistema plantio direto e convencional: Efeito na produtividade de fibra de três cultivares de algodoeiro. Revista de Agricultura Neotropical, 3(2), 34-40. Retrieved from https://periodicosonline.uems.br/index.php/agrineo/article/view/ $846 / 988$

Lima, C. L. R. de, Pauletto, E. A., Gomes, A. da S., Hartwig, M. P., \& Passianoto, C. C. (2006). Compactação de um Planossolo em função de sistemas de manejo. Revista Brasileira de Agrociência, 12(2), $179-182$. https://doi.org/10.18539/CAST.V12I2.4521

Nagahama, H. J., Granja, G. P., Cortez, J. W., Ramos, R. L., \& Arcoverde, S. N. S. (2016). Efeitos da escarificação mecânica nos atributos físicos do solo e agronômicos do capim elefante. Revista Ceres, 63(5), 741-746. https://doi.org/10.1590/0034-737x201663050020

Oliveira, M. P., Roque, C. G., Borges, M. C. R. Z., Oliveira, R. P., \& Nogueira, K. B. (2017). Efeito residual da gessagem e calagem na resistência à penetração obtida com dois penetrômetros em diferentes sistemas de manejo. Revista de Agricultura Neotropical, 4(1), 58-64. Retrieved from https://periodicosonline.uems.br/ index.php/agrineo/article/view/1208/1265

Raij, B. V. (2008). Gesso na agricultura (p. 233). Campinas: Instituto Agronômico. Retrieved from http:/www.ipni.net/publication/ia-brasil.nsf/0/B85CBF8A11ADF43E83257A90007E3924/\$FILE/Page26-2 7-122.pdf

Ramos, B. Z., Toledo, J. P. V. F., Lima, J. M. L., Serafim, M. E., Bastos, A. R. R., Guimarães, P. T. G., \& Coscione, A. R. (2013). Doses de gesso em cafeeiro: influência nos teores de cálcio, magnésio, potássio e pH na solução de um Latossolo Vermelho distrófico. Revista Brasileira de Ciência do Solo, 37, 1018-1026. https://doi.org/10.1590/S0100-06832013000400019

Reichert, J. M., Suzuki, L. E. A. S., Reinert, D. J., Horn, R., \& Hâkansson, I. (2009). Reference bulk density and critical degree-of-compactness for no-till crop production in subtropical highly weathered soils. Soil Tillage Res., 102, 242-254. https://doi.org/10.1016/j.still.2008.07.002

Reinert, D. J., Albuquerque, J. A., Reichert, J. M., Aita, C., \& Andrada, M. M. C. (2008). Limites críticos de densidade do solo para o crescimento de raízes de plantas de cobertura em Argissolo Vermelho. Revista Brasileira de Ciência do Solo, 32, 1805-1816. https://doi.org/10.1590/S0100-06832008000500002

Silva, A. P., \& Kay, B. D. (1997). Estimating the least limiting water range of soils from properties and management. Soil Science Society of America Journal, 61(3). 877-883. https://doi.org/10.2136/036159950 06100030023x

Soares, M. D. R., Campos, M. C. C., Oliveira, I. A., Cunha, J. M., \& Santos, L. A. C. (2016). Atributos físicos do solo em áreas sob diferentes sistemas de usos na região de Manicoré. Ciências Agrárias, 59(1), 9-15. https://doi.org/10.4322/rca.2020

Stone, L. F., Silveira, P. M., \& Moreira, J. A. A. (2012). Efeitos do sistema plantio direto no uso da água pelas culturas e no manejo da irrigação. Embrapa Arroz e Feijão, 207. Retrieved from https://www.embrapa.br/ busca-de-publicacoes/-/publicacao/928965/efeitos-do-sistema-plantio-direto-no-uso-da-agua-pelas-culturase-no manejo-da-irrigação

Veiga, M., Reinert, D. J., Reichert, J. M., \& Kaiser, D. R. (2008). Short and long-term effects of tillage systems and nutrient sources on soil physical properties of a southern Brazilian Hapludox. Revista Brasileira de Ciência do Solo, 32(4), 1437-1446. https://doi.org/10.1590/S0100-06832008000400008 
Vitória, E. L. da, Fernandes, H. C., Texeira, M. M., \& Cecon, P. R. (2014). Produtividade de plantas forrageiras em função de manejo do solo. Engenharia Agrícola, 34(5), 955-962. https://doi.org/10.1590/S0100-6916 2014000500014

\section{Copyrights}

Copyright for this article is retained by the author (s), with first publication rights granted to the journal.

This is an open-access article distributed under the terms and conditions of the Creative Commons Attribution license (http://creativecommons.org/licenses/by/4.0/). 